\title{
Article \\ Evaluation of Host Resistance, Hydrated Lime, and Weed Control to Manage Clubroot in Canola
}

\author{
Brittany C. Hennig ${ }^{1}$, Sheau-Fang Hwang ${ }^{1}$, Victor P. Manolii ${ }^{1}$, George Turnbull ${ }^{2}$, Samuel V. J. Robinson ${ }^{3}$ (D) \\ and Stephen E. Strelkov $1, *$ (D)
}

1 Department of Agricultural, Food and Nutritional Science, University of Alberta, Edmonton, AB T6G 2P5, Canada; bch@ualberta.ca (B.C.H.); sh20@ualberta.ca (S.-F.H.); vmanolii@ualberta.ca (V.P.M.)

2 Crop Diversification Centre North, Alberta Agriculture, Forestry and Rural Economic Development, 17507 Fort Rd NW, Edmonton, AB T5Y 6A8, Canada; gturnbul@telusplanet.net

3 Department of Biological Sciences, University of Calgary, Calgary, AB T2N 4V8, Canada; samuel.robinson@ucalgary.ca

* Correspondence: strelkov@ualberta.ca; Tel.: +1-780-492-1969

Citation: Hennig, B.C.; Hwang, S.-F.; Manolii, V.P.; Turnbull, G.; Robinson, S.V.J.; Strelkov, S.E. Evaluation of Host Resistance, Hydrated Lime, and Weed Control to Manage Clubroot in Canola. Horticulturae 2022, 8, 215. https://doi.org/10.3390/ horticulturae 8030215 Academic Editor: Harald Scherm

Received: 22 December 2021 Accepted: 26 February 2022 Published: 1 March 2022

Publisher's Note: MDPI stays neutral with regard to jurisdictional claims in published maps and institutional affiliations.

Copyright: (C) 2022 by the authors. Licensee MDPI, Basel, Switzerland. This article is an open access article distributed under the terms and conditions of the Creative Commons Attribution (CC BY) license (https:// creativecommons.org/licenses/by/ $4.0 /)$.

\begin{abstract}
Plasmodiophora brassicae Wor. is a soilborne parasite causing clubroot of canola (Brassica napus L.), a serious disease managed mostly by planting clubroot-resistant (CR) cultivars. Recently, new pathotypes of $P$. brassicae have emerged that overcome resistance, highlighting the need for a greater understanding of resistance stewardship and an integrated approach to clubroot management. Replicated field experiments were conducted in Edmonton, AB, in 2018 and 2019, to evaluate the effect of lime application and weed management on clubroot severity, crop yield and various growth parameters in clubroot-susceptible (CS) and CR canola cultivars. P. brassicae resting spore densities were also monitored by quantitative PCR for each treatment. When hydrated lime was applied to increase the soil $\mathrm{pH}$ from initial values of 5.2-5.5 to 7.2, clubroot severity decreased by $34-36 \%$ in the CS canola cultivar, while seed yield increased by $70-98 \%$. The application of hydrated lime also resulted in resting spore densities that were $48-80 \%$ lower, relative to untreated controls, in plots where the CS cultivar was grown. Lime application or management of weeds did not significantly affect spore densities in plots with the CR cultivar. The results from the field trial suggest that the application of hydrated lime may be a useful strategy to manage clubroot, when used in combination with genetic resistance to reduce disease pressure.
\end{abstract}

Keywords: canola; clubroot; clubroot resistance; lime; management; Plasmodiophora brassicae; soil; weed control

\section{Introduction}

Clubroot, caused by the obligate parasite Plasmodiophora brassicae Woronin, is a soilborne disease of the Brassicaceae family. All species within this family are potential hosts of P. brassicae [1], which causes estimated losses of $10-15 \%$ worldwide [2]. Clubroot is an increasing threat to the production of cultivated brassica vegetables and non-vegetable oilseeds around the world. The severity of symptoms and crop losses from this disease are related in large part to the frequency of cultivation of susceptible crops, and therefore, clubroot is a 'disease of cultivation' [1]. The predominant visual symptom of clubroot is a swelling of the host roots, resulting in distinct galls or clubs on susceptible hosts. This swelling reflects hypertrophy and hyperplasia of the root tissues, which can in turn restrict nutrient and water movement within the host. Aboveground symptoms such as stunting, wilting, leaf discoloration, and premature ripening develop as a result [1].

Clubroot is not a new disease to Canada, with symptoms on cabbage, cauliflower, Chinese cabbage, and turnip documented in the Canadian Plant Disease Survey by the 1920s. Throughout the 20th century, clubroot was a familiar disease affecting cultivated vegetables 
across British Columbia, Ontario, Quebec, and the Maritimes [3]. However, although there were isolated reports of clubroot on Brassica oilseed crops in Newfoundland [4] and Quebec [5], clubroot was not confirmed on canola (Brassica napus L.) in western Canada until 2003 [6], when a dozen infected crops were found in central Alberta. Since 2003, clubroot has spread across most canola producing regions in the province, and now is also found with increasing frequency in Saskatchewan and Manitoba [7-10]. Canola yields can decline significantly due to $P$. brassicae infection, with the potential for complete yield losses in severe cases [11,12]. The effective management of clubroot in canola is essential, as this crop contributes approximately $\$ 26.7$ billion CAD annually to the Canadian economy [13]

When clubroot was first identified on canola in Alberta [6], few disease management strategies were available to growers until the first CR cultivar (' $\left.45 \mathrm{H} 29^{\prime}\right)$ was registered in 2009. Additional resistant cultivars became available soon afterwards, and as P. brassicae spread and inoculum levels rose in infested fields, growers relied heavily on the planting of CR canola for effective clubroot control. Most of the resistant cultivars released, at least initially, appeared to carry single-gene resistance $[14,15]$. Unfortunately, since 2013, clubroot resistance has been broken in an increasing number of fields, reflecting the emergence of new, highly virulent pathotypes of $P$. brassicae as a result of the selection pressure imposed by CR canola [16-18]. This loss in the effectiveness of resistance has increased interest in other management strategies, including the application of lime to increase soil $\mathrm{pH}$ [19]. Liming, which is one of the oldest and most common practices for clubroot management, makes conditions less favorable for disease development, since $P$. brassicae is known to favor acidic soils [20]. A recent study in Alberta indicated some potential for hydrated lime as a tool for clubroot control [19]. Effective weed management, particularly of cruciferous weeds and volunteer canola that could serve as alternative hosts, may also be important in mitigating clubroot [21].

As resistance-breaking pathotypes of $P$. brassicae become more widespread, the adoption of multiple approaches for clubroot control will become critical for the sustainable management of this disease. The general aim of this study was to evaluate the effect of various management practices and approaches on P. brassicae inoculum levels and clubroot incidence and severity. The specific objective was to compare the effectiveness of the application of hydrated lime, weed management and the deployment of CR genetics on clubroot severity, incidence, and yield.

\section{Materials and Methods}

\subsection{Field Analysis}

Replicated field trials were conducted in 2018 (site 1) and 2019 (sites 2 and 3) to study the effect of various combinations of clubroot management strategies (resistance, soil liming and weed control) on disease severity, yield, and P. brassicae spore density. The trials were located in a naturally infested clubroot nursery at the Crop Diversification Centre North (CDCN; $\left.53^{\circ} 38^{\prime} \mathrm{N}, 113^{\circ} 21^{\prime} \mathrm{W}\right)$, Alberta Agriculture, Forestry and Rural Economic Development, Edmonton, Alberta. The soil at this site consists of a Black Chernozem. Each trial included four replicates arranged in a randomized complete block design. There were eight different combinations of the management strategies, creating a block-split-split plot design. Each plot had an area of $9 \mathrm{~m}^{2}(1.5 \mathrm{~m} \times 6 \mathrm{~m})$, with 4 rows per plot and a $2 \mathrm{~m}$ buffer between replicates.

The pre-treatment $\mathrm{pH}$ of the soil at site 1 (2018) was 5.3, while at sites 2 and 3 (2019), the soil $\mathrm{pH}$ values were 5.23 and 5.48 , respectively. The amount of lime needed to reach the target $\mathrm{pH}$ of 7.2 was calculated based on recommendations from the Government of Alberta [22] at site 1 in 2018, or following Penney [23] at sites 2 and 3 in 2019. Hydrated lime $\left(\mathrm{Ca}(\mathrm{OH})_{2}\right.$, Graymont) was applied evenly, by hand, on May 28th, $2018\left(14.09 \mathrm{~T} \mathrm{ha}^{-1}\right.$, site 1) and 31 May 2019 (11.49 T ha ${ }^{-1}$, site 2; and $8.60 \mathrm{~T} \mathrm{ha}^{-1}$, site 3). The seedbed was prepped with a rototiller, which was used for a second time to incorporate the lime to a depth of $10 \mathrm{~cm}$. Due to a lack of moisture in 2019 at the time of seeding, $30 \mathrm{~L}$ of water was applied per plot immediately following the lime application. 
In 2018, a CR canola cultivar '45H29' (Dupont Pioneer, Mississauga, ON, Canada) and a CS cultivar '45H31' (Dupont Pioneer) were seeded at site 1. The development of clubroot galls was observed on the resistant variety during the growing season. Pathotyping of some of these galls indicated a virulence shift in this nursery from pathotype $3 \mathrm{H}$ to $3 \mathrm{D}$, as defined on the Canadian Clubroot Differential set, the latter of which can overcome the resistance in '45H29' [17]. Therefore, in 2019, '45H29' was replaced with '45CM39' (Dupont Pioneer), a canola cultivar with 'second generation' resistance effective against pathotypes 2B, 3A, 3D and 5X. The trials were seeded on 5 June 2018 and 2019, using a Fabro gravity seeder with double disk openers (Swift Current, SK, Canada) at a depth of $2.5 \mathrm{~cm}$.

Plots that required weed control were hand-weeded every two weeks after the canola emerged until the end of July (2018 and 2019). Hand weeding ensured that no galls developed on any susceptible weeds, which could have affected the $P$. brassicae spore densities. Both susceptible and non-susceptible weeds were counted in non-weeded plots, but the proportion of susceptible weeds was strongly correlated with overall weed density $(\mathrm{r}=0.86, n=64, p<0.0001)$, and model results using overall weed density or proportion of susceptible weeds as continuous variables were not substantially different from models with weed presence/absence, so we excluded this from further analysis. No herbicides were applied in either year at any site.

Shoot height, shoot weight, and clubroot symptoms were evaluated on 10 plants per plot on 31 July 2018 (site 1) and 30 July 2019 (sites 2 and 3). Each root was rated on a 0 to 3 scale, where: $0=$ no galling, $1=$ small galling, $2=$ moderate galling, and $3=$ severe galling [24]. Root and gall weights were also measured after the ratings were complete. The ratings were then used to calculate the index of disease (ID) for each plot, according to the equation of Horiuchi and Hori [25] as modified by Strelkov et al. [26]:

$$
\mathrm{ID}(\%)=\frac{\sum(n \times 0+n \times 1+n \times 2+n \times 3)}{\mathrm{N} \times 3} \times 100
$$

where $n=$ number of plants in a class; $\mathrm{N}=$ is the total number of plants; and $0,1,2,3=$ symptom severity classes.

Reglone Ion (Syngenta, Guelph, ON, Canada) was applied as a desiccant to the plots on 24 September 2018 and 26 September 2019, at a rate of $6.10 \mathrm{~L} / \mathrm{ha}$, to ensure proper dry down of the canola crop and weeds for harvest. The harvested seeds were cleaned and dried at air temperature before they were weighed to obtain yield estimates. In the spring of 2020, 10 soil samples per plot were collected from sites 2 and 3 with a $10 \mathrm{~cm}$ Dutch auger. To maintain consistency throughout sampling, five samples were taken within rows and five samples were taken between rows. The Dutch auger was washed with $80 \%$ ethanol between samples to prevent cross-contamination. The samples were stored at room temperature until used for quantitative PCR analysis of soil inoculum density. Unfortunately, at site 1, the plots were cultivated with a tractor shortly following the growth season, precluding the collection of soil samples in the following spring.

\subsection{PCR Analysis}

Soil samples collected from the field plots were air-dried at room temperature and homogenized with an electric grinder (Waring Commercial, Stamford, CT, USA) that was washed with an $80 \%$ ethanol solution between samples. Total genomic DNA was extracted from $0.25 \mathrm{~g}$ of each sample with a DNeasy ${ }^{\circledR}$ PowerSoil ${ }^{\circledR}$ Kit (Qiagen, Germantown, MD, USA) according to the manufacturer's instructions. The concentration and quality of the DNA was estimated with a Nanodrop 2000c spectrophotometer (Thermo Fisher Scientific Inc., Waltham, MA, USA) and then stored at $-20^{\circ} \mathrm{C}$ until preparation for PCR analysis.

The DNA samples were prepared for conventional PCR by dilution with nucleasefree water (Thermo Fisher Scientific Inc.) to a concentration of $2 \mathrm{ng} \mu \mathrm{L}^{-1}$. Conventional PCR analysis was conducted following Cao et al. [27] with the primers TC1F and TC1R. Negative controls included $5 \mu \mathrm{L}$ nuclease-free water instead of a DNA template, while the positive controls included $10 \mathrm{ng}$ of $P$. brassicae DNA. Reaction products were visualized on 
$2 \%$ agarose gels stained with 1 X SYBR Safe (Invitrogen, Carlsbad, CA, USA). Samples that tested positive for the presence of $P$. brassicae DNA by conventional PCR were analyzed further by quantitative PCR (qPCR). Briefly, the DNA samples were diluted 10-fold with nuclease-free water and subjected to GPCR analysis with the primers DR1F and DR1R as per Rennie et al. [28] in a StepOnePlus Real Time PCR System (Applied Biosystems, Foster City, CA, USA). The resting spore density in each sample was estimated relative to a standard curve generated with known amounts of $P$. brassicae inoculum $\left(1 \times 10^{2}, 1 \times 10^{3}\right.$, $1 \times 10^{4}, 1 \times 10^{5}$, and $1 \times 10^{6}$ resting spores $\mathrm{g}^{-1}$ soil; [28]).

\subsection{Statistical Analysis}

Data were analyzed with R v. 4.1.2 [29]. Plant response variables analyzed included P. brassicae gall weight, shoot weight, shoot height, resting spore density, index of disease, and yield, and predictors included a three-way interaction of genetics (susceptible/not susceptible), hydrated lime (lime/no lime), and weeds (weeds/no weeds). Site:year combinations and greenhouse blocks were added as random intercepts to account for betweensite:year and between-block differences (variance components for random intercepts are shown in Table A1). We did not test for interactions between management factors and year, as there was not enough replication. Residual plots were used to visualize the normality and homoscedasticity of the model residuals and random intercept distributions. The spore density and gall disease data were log transformed to meet assumptions of residual, and disease index was logit-transformed. A type-II ("sequential") ANOVA was carried out on fitted models in order to properly account for interactions, and a post-hoc test of betweengroup differences was performed, correcting for multiple comparisons. Differences were considered statistically significant if $p<0.05$. nlme was used to fit mixed-effects models, emmeans and multcomp were used for post-hoc comparisons, and ggplot2, ggeffects, and ggpubr were used to display model results [30-35]. The data and the R code required for analysis can be found in the Supplementary Material.

\section{Results}

\subsection{Resting Spore Densities}

The effect of canola cultivar and hydrated lime on $P$. brassicae resting spore density was significant $(p<0.0001$ and $p=0.03$, respectively; Table 1$)$, and the three-way interaction between the cultivar, hydrated lime, and weed management was close to significance $(p=0.0825$; Table 1; Figure 1A). Spore densities in the treatments that included the CR cultivar ' $45 \mathrm{CM} 39$ ' and the application of hydrated lime or weed management were all lower than the treatments that included the susceptible cultivar ' $45 \mathrm{H} 31^{\prime}$ ' without the application of hydrated lime (Figure 1A). Hydrated lime plots had $48-80 \%$ lower resting spore densities, relative to untreated controls, in plots where the CS cultivar was grown (Figure 1A, note $\log$-scale).

Table 1. Three-way ANOVA with REML mixed-model analysis for field trials evaluating the effects of clubroot resistance, soil liming and weed control for the management of Plasmodiophora brassicae on canola at three naturally infested field sites in Edmonton, AB, Canada, in 2018 and 2019; $p$-values $<0.05$ are in bold.

\begin{tabular}{cccccccccc}
\hline & \multicolumn{3}{c}{ Gall Weight } & \multicolumn{3}{c}{ Shoot Weight } & \multicolumn{3}{c}{ Shoot Height } \\
\cline { 2 - 9 } & DF & F-Value & $p$-Value & DF & F-Value & $p$-Value & DF & F-Value & $p$-Value \\
\hline Genetics $^{\text {a }}$ & 1,77 & 162.77 & $<\mathbf{0 . 0 0 0 1}$ & 1,77 & 43.49 & $<\mathbf{0 . 0 0 0 1}$ & 1,77 & 66.72 & $<0.0001$ \\
Lime $^{\mathrm{b}}$ & 1,77 & 17.65 & $\mathbf{0 . 0 0 0 1}$ & 1,77 & 35.68 & $<\mathbf{0 . 0 0 0 1}$ & 1,77 & 6.47 & $\mathbf{0 . 0 1 3 0}$ \\
Weeds $^{c}$ & 1,77 & 0.54 & 0.4654 & 1,77 & 20.10 & $<\mathbf{0 . 0 0 0 1}$ & 1,77 & 0.07 & 0.7863 \\
Genetics:Lime $_{\text {Genetics:Weeds }}$ & 1,77 & 0.31 & 0.5772 & 1,77 & 0.08 & 0.7838 & 1,77 & 12.98 & $\mathbf{0 . 0 0 0 6}$ \\
Lime:Weeds & 1,77 & 0.15 & 0.6971 & 1,77 & 2.31 & 0.1323 & 1,77 & 0.31 & 0.5766 \\
Genetics:Lime:Weeds & 1,77 & 0.04 & 0.8409 & 1,77 & 0.43 & 0.5144 & 1,77 & 3.58 & 0.0623 \\
\hline
\end{tabular}


Table 1. Cont.

\begin{tabular}{|c|c|c|c|c|c|c|c|c|c|}
\hline & \multicolumn{3}{|c|}{ Index of Disease Rating } & \multicolumn{3}{|c|}{ Yield } & \multicolumn{3}{|c|}{ Spore Density (Sites $2 \& 3$ only) } \\
\hline & $\mathrm{DF}$ & F-value & $p$-value & DF & F-value & $p$-value & DF & F-value & $p$-value \\
\hline Genetics $^{a}$ & 1,77 & 167.96 & $<0.0001$ & 1,77 & 82.90 & $<0.0001$ & 1,49 & 124.27 & $<0.0001$ \\
\hline Lime $^{b}$ & 1,77 & 31.28 & $<0.0001$ & 1,77 & 15.00 & 0.0002 & 1,49 & 4.98 & 0.0302 \\
\hline Weeds ${ }^{c}$ & 1,77 & 1.13 & 0.2916 & 1,77 & 29.70 & $<0.0001$ & 1,49 & 0.66 & 0.4202 \\
\hline Genetics:Lime & 1,77 & 2.49 & 0.1187 & 1,77 & 23.12 & $<0.0001$ & 1,49 & 0.80 & 0.3743 \\
\hline Genetics:Weeds & 1,77 & 0.01 & 0.9432 & 1,77 & 3.33 & 0.0718 & 1,49 & 0.84 & 0.3642 \\
\hline Lime:Weeds & 1,77 & 0.04 & 0.8417 & 1,77 & $<0.01$ & 0.9847 & 1,49 & 1.09 & 0.3011 \\
\hline Genetics:Lime:Weeds & 1,77 & 0.30 & 0.5874 & 1,77 & 0.01 & 0.9408 & 1,49 & 3.14 & 0.0825 \\
\hline
\end{tabular}

a 'Genetics' refers to the canola cultivar grown (clubroot-susceptible ' $45 \mathrm{H} 31^{\prime}$ ' or clubroot-resistant '45H29' at site $1 \&$ '45CM39' at sites 2 and 3). ${ }^{b}$ 'Lime' refers to either the application of hydrated lime or no application. $c$ 'Weeds' refers to either the management or non-management of weeds.
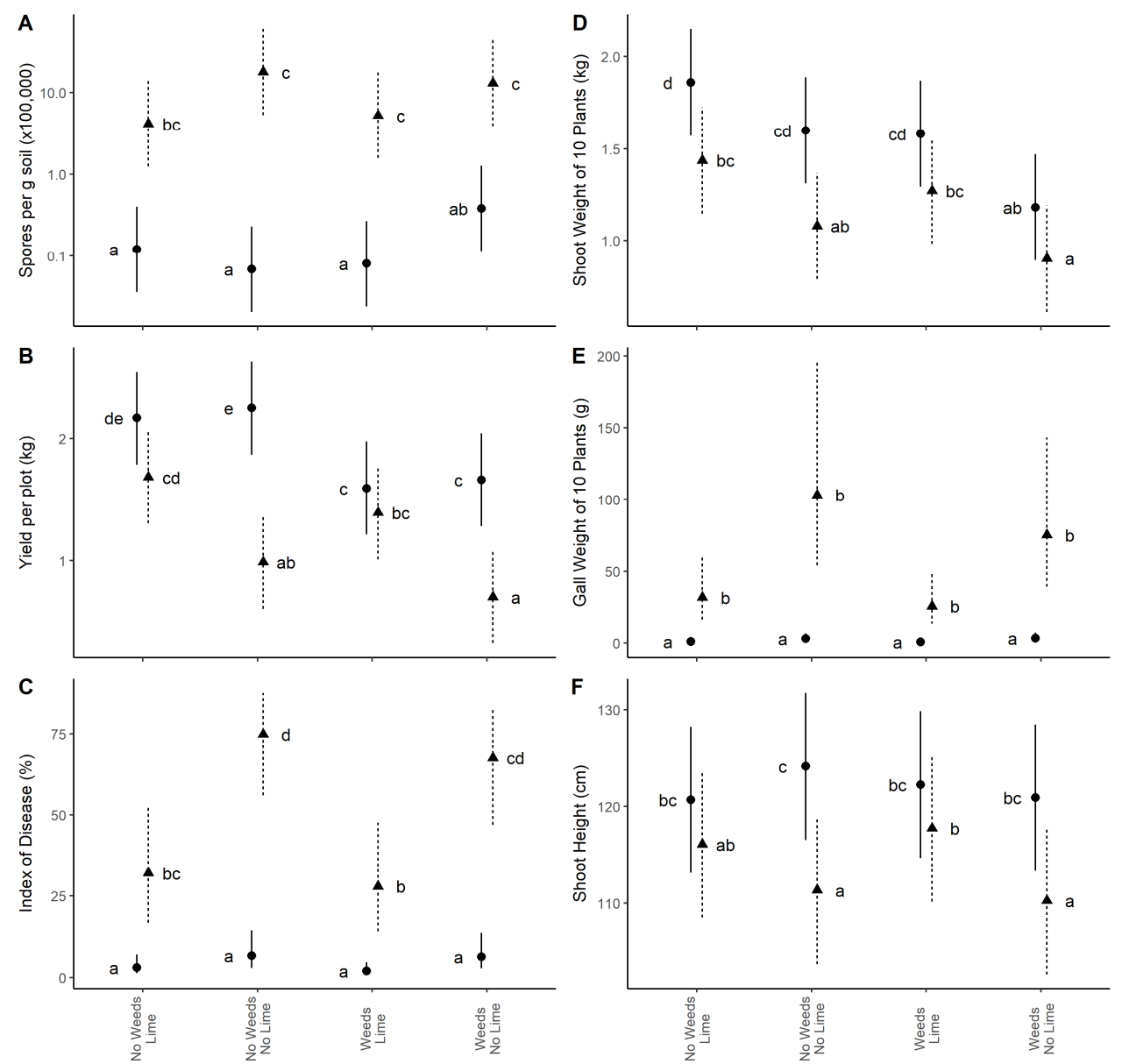

Resistant 4 Susceptible

Figure 1. (A) Amount (spores) of Plasmodiophora brassicae in the soil, (B) canola yield, (C) index of disease, (D) shoot weight, (E) gall weight, and (F) shoot height in field plot experiments conducted at three field sites in Edmonton, AB, in 2018 and 2019. Differences in means are denoted by different letters at $p<0.05$. The whiskers represent the standard errors of prediction $\times 1.96$.

\subsection{Clubroot Severity}

The effect of canola cultivar and hydrated lime on clubroot disease severity was significant $(p<0.0001$; Table 1). Within the treatments that included the CR cultivar ' $45 \mathrm{CM} 39$ ', there was no difference in clubroot severity between treatments using no hydrated lime with and without weed management (Figure 1C). Within the treatments using the susceptible cultivar ' $45 \mathrm{H} 31$ ', clubroot severity in plots with hydrated lime decreased by $34-36 \%$ relative to those without hydrated lime (Figure 1C). 


\subsection{Yield}

The effect of canola cultivar, the application of hydrated lime, and management of weeds, as well as the interaction between cultivar and the application of hydrated lime on yield, were all significant (all $p=0.0002$ Table 1 ; Figure 1B), and the interaction between cultivar and weed management was close to significance $(p=0.07)$. The treatments that included the CR cultivar '45CM39' with weed management showed the largest difference from the treatments that included the susceptible cultivar ' $45 \mathrm{H} 31$ ' without the application of hydrated lime (Figure 1). Yields in the treatments using the CR cultivar '45CM39' with unmanaged weeds were not significantly different from treatments that included the susceptible cultivar ' $45 \mathrm{H} 31$ ' with the application of hydrated lime (Figure 1C). Hydrated lime increased seed yield by $70-98 \%$ in the CS canola cultivar (Figure 1C).

\subsection{Growth Parameters}

The effect of canola cultivar and the application of hydrated lime on gall weight was significant $(p<0.0001$; Table 1$)$. The greatest difference was observed between treatments that included a CR cultivar and treatments that used a susceptible cultivar without the application of hydrated lime (Figure 1E). Gall weight was lower when hydrated lime was applied to treatments using a susceptible cultivar (Figure 1E).

Canola cultivar, the application of hydrated lime, and the management of weeds all had significant effects on shoot weight (all $p<0.0001$; Table 1 ). Treatments using a CR canola cultivar with the application of hydrated lime and/or managed weeds were similar, and had significantly greater shoot weights relative to all other treatments. In contrast, when the CR cultivar was grown in the absence of hydrated lime or weed management, shoot weight was not significantly different from treatments with a susceptible canola cultivar when either no hydrated lime was applied or the weeds were not managed (Figure 1D).

The effects of canola cultivar, application of hydrated lime, and the interaction between canola cultivar and lime on shoot height were significant $(p<0.0001,0.013$, and 0.0006 , respectively), and the interaction between lime and weed management also approached significance ( $p=0.06$; Table 1$)$. There was no significant difference between treatments when using a CR cultivar, although they were mostly greater than treatments with a susceptible cultivar and no application of hydrated lime (Figure 1F). Finally, the treatments that included the CR cultivar with no application of hydrated lime and managed weeds had significantly taller plants than all treatments with a susceptible canola cultivar (Figure 1F).

\section{Discussion}

Based on the results, it appears that genetic resistance in the host remains the most effective tool for managing clubroot of canola in P. brassicae-infested soil. The clubroot index of disease (ID) was reduced by an average of $41 \%$, relative to the CS cultivar, when the $\mathrm{CR}$ cultivar was grown. This is consistent with previous studies, which have shown that resistance significantly reduced clubroot development in canola [36,37]. Nonetheless, the efficacy of genetic resistance will depend on the predominant pathotypes of $P$. brassicae present in the field [38]. Many 'novel' pathotypes of $P$. brassicae have emerged in recent years, about half of which can overcome the resistance in most CR canola cultivars $[17,18,39]$. While the genetic basis of the resistance in commercial cultivars is not generally in the public domain, it appears to be similar in most varieties introduced after the initial identification of clubroot [40], and is now often referred to as 'first generation' resistance [18]. The CR cultivar '45CM39' included in this study, however, is among a select group of newer genotypes carrying 'second generation' resistance. The resistance in these cultivars is reportedly distinct from first generation resistance and was developed to manage pathotypes of P. brassicae that can overcome the latter [41]. The presence of pathotype 3D, which is one of the main pathotypes able to break first generation resistance [17], has been confirmed in the disease nursery where these trials were conducted (see Section 2). Thus, the significant reduction in clubroot severity on '45CM39' is likely to reflect appropriate cultivar selection and the efficacy of its clubroot resistance. The reduced clubroot symptom development 
in '45CM39' was reflected in improved overall plant health and yield; the resistant variety showed significant increases in shoot height, shoot weight, and amount of harvested seed relative to the CS cultivar. The selection of an appropriate CR cultivar allows the canola plant to establish, grow, and produce seed with minimal impact from P. brassicae.

Cropping of the CS cultivar resulted, on average, in $2.1 \times 10^{7}$ more resting spores per gram of soil relative to a CR cultivar in the spring following cultivation. Similar results were reported in earlier comparisons of the resting spore contributions from CS and CR canola [36,42]. This highlights the positive impact of growing a CR cultivar with respect to $P$. brassicae inoculum management. Gall development is greatly reduced on resistant hosts, and as such the production of new resting spores that can be released back into the soil also is reduced [21,43]. Nonetheless, the spores that are produced on CR canola, while less in number, may be enriched for pathotypes able to overcome the resistance, and may contribute to virulence shifts [43].

While there was no significant interaction between lime treatment and cultivar, the most notable differences in clubroot severity were observed for the CS cultivar, where treatment with lime resulted in a decline in clubroot severity of about $35 \%$, while the yield almost doubled. This is consistent with the results of earlier studies, which showed some potential for the application of lime to mitigate clubroot $[19,20,44]$. Lime could be a particularly useful tool to manage clubroot in patches where resistance-breaking pathotypes are predominant and resistance is no longer effective. It could also serve as a tool to supplement genetic resistance before it is lost or eroded, since the application of lime resulted in a decrease in clubroot severity even on the CR cultivar. This suggests that combining genetic resistance with lime could slow increases in P. brassicae inoculum in the soil, and hence extend the durability of resistant varieties. Hydrated lime, however, did not have a significant effect on yield in the CR cultivar, but some numerical decreases were observed in the yield of the CR variety following lime treatment. This could reflect changes in soil nutrient availability for the host because of increased $\mathrm{pH}[45,46]$. Tremblay et al. [44] also observed reduced clubroot severity on cauliflower (Brassica oleracea L. var. botrytis) without a concomitant yield increase following spring application of calcium hydroxide. Collectively, the results from this study suggest that the application of hydrated lime should target a soil pH of 7.2.

The management of weeds resulted in significantly higher yield for the CR canola cultivar, but the effect of weed management on yield of the CS cultivar was not significant. Weeds compete with crops for nutrients, water, and space [47]. As such, weed control is part of a good crop management plan and can result in higher yields. In the case of the CS canola cultivar, weed control did not affect clubroot severity among treatments with similar cultivar and lime regimes. The negative effects associated with severe clubroot development may have prevented the CS cultivar from taking full advantage of the increased resources available with weed control.

The CR cultivar treatments without weed management had yields that were similar to the treatments that included a CS cultivar with hydrated lime. While the cropping of a CS cultivar in a P. brassicae-infested soil is not recommended, since variation in environmental conditions or timing of the lime treatment can still result in development of disease [19], these results do highlight the potential effectiveness of combining strategies for clubroot management. By reducing disease pressure, control measures such as the application of lime may help to prolong the effectiveness of resistance, thereby contributing to the stewardship of this important resource.

Resting spore densities were numerically highest when the CS cultivar was grown without hydrated lime and with weed management, although these differences were not significantly different. This suggests that a more acidic soil may increase the number of resting spores produced in the more severely infected host tissues. Additionally, it is possible that the absence of weeds increased access to the canola roots by the resting spores, promoting more secondary infections, since no weed roots would have been present. A challenge associated with measuring the effects of weeds in the field can be the uneven distribution 
of weed species and quantity. Clubroot-susceptible weeds were found across sites 2 and 3 , including shepherd's purse (Capsella bursa-pastoris L.), stinkweed (Thlaspi arvense L.), and flixweed (Descurainia sophia L.). However, there were $15.75 \%$ more clubroot-susceptible weeds across site 3 than site 2 (Table A2). Furthermore, across site 3, the proportion of susceptible weeds in the plots varied from as low as $15 \%$ to as high as $82 \%$. At site 2 , the highest proportion of clubroot-susceptible weeds in any plot was $57 \%$. As the linear mixedeffects model used presence/absence of weeds rather than proportion of susceptible weeds, no conclusions can be made on the effects of clubroot-susceptible weeds on inoculum levels. However, we hypothesize that the hydrated lime inhibited spore germination, which suppressed clubroot severity on susceptible weeds, affecting the spore density [48]. In the plots where weeds were managed, frequent hand-weeding was completed as necessary to prevent an increase in inoculum levels resulting from the proliferation of $P$. brassicae in these hosts [21].

As more growers face the challenges posed by clubroot and resistance-breaking pathotypes of $P$. brassicae, there has been an increased interest in liming as a clubroot management tool. However, limited research exists on which lime product to select for different soil types and inoculum levels, as well as on the optimal rate of lime to apply. In this research, hydrated lime was evaluated as a treatment because a previous study had confirmed its effectiveness in the same clubroot nursery [19]. Future studies will need to determine which lime products are best suited for the various soil types found across the Canadian prairies, and how to assess appropriately the optimal amount of lime required. As liming can be costly, growers need more regional and applied research to ensure their efforts at clubroot management are successful, without negatively affecting their canola crops. More research is also needed to understand the longevity of various liming products in the soil. Due to different quality standards and associated costs of lime products, knowledge of the differences with respect to the frequency of application is important to encourage their use as another clubroot management tool.

The influence of cruciferous weeds on P. brassicae also requires more research. Weeds grow continuously throughout the cropping season. Therefore, it would be beneficial to determine when the weed is most susceptible to infection and if $P$. brassicae spores are equally virulent throughout the growing season. Additionally, studying whether cruciferous weeds are susceptible to all pathotypes equally will enhance our knowledge of pathotype spread and proliferation. If there are weed species that are naturally resistant to specific pathotypes, the basis for resistance in these weeds could be investigated for potential integration into canola for more durable clubroot resistance. Non-host weeds should also be studied to understand their contribution to $P$. brassicae inoculum levels. Ultimately, a comprehensive research approach, taking into consideration the needs of growers and making use of all available tools, will help to move forward our understanding of the clubroot pathosystem and its management.

\section{Conclusions}

The necessity and importance of a proactive and integrated clubroot management plan is well established [3,37,49-51]. Results from this research reinforce why CR cultivars have been the first line of defence against clubroot across the prairies. When the appropriate CR cultivar is selected for the predominant pathotype in a field, clubroot may seem to be 'completely controlled'. However, this can provide growers with a false sense of security. Given the rapid emergence of novel pathotypes able to overcome resistance [16-18], the control afforded by CR canola may soon be lost, along with the most used and effective clubroot management tool. Proper stewardship will prolong the longevity of CR canola cultivars. Stewardship measures include early identification of clubroot in a field, the deployment of $\mathrm{CR}$ genetics before the disease becomes established and reducing the number of times the pathogen is exposed to the same sources of resistance. Individually, hydrated lime or weed management will not provide the same short-term benefits as CR cultivars. However, using these strategies collectively to limit infection and to create an unfavourable 
environment for the pathogen could help to protect resistance. Such an integrated approach will reduce clubroot disease incidence and severity, help to control P. brassicae inoculum levels, and ultimately increase canola yield for growers.

Supplementary Materials: The following are available online at https:/ /www.mdpi.com/article/10 .3390 /horticulturae $8030215 / \mathrm{s} 1$, the raw data and R code used to run the analysis.

Author Contributions: Conceptualization, B.C.H., S.E.S. and S.-F.H.; methodology, B.C.H., V.P.M. and G.T.; formal analysis, B.C.H. and S.V.J.R.; resources, S.E.S. and S.-F.H.; data curation, B.C.H., S.E.S. and S.-F.H.; writing-original draft preparation, B.C.H.; writing-review and editing, S.E.S.; supervision, S.E.S. and S.-F.H.; project administration, S.E.S. and S.-F.H.; funding acquisition, S.E.S. and S.-F.H. All authors have read and agreed to the published version of the manuscript.

Funding: This research was funded by the Alberta Canola Producers Commission and Results Driven Agriculture Research (Project 2019F076R), and by Agriculture and Agri-Food Canada and the Canola Council of Canada through the Canadian Agricultural Partnership (CAP) Program (Activity 5.9 P1 Cluster). The University of Alberta and Alberta Agriculture, Forestry and Rural Economic Development provided in-kind support.

Institutional Review Board Statement: Not applicable.

Informed Consent Statement: Not applicable.

Data Availability Statement: The data presented in this study are available in the Supplementary Material found online, and available on request from the corresponding author.

Acknowledgments: The authors thank Ileana Strelkov (U of A) for assistance and training of the first author on the qPCR and related analyses. In addition, the authors acknowledge the assistance of several summer students from the $U$ of A Plant Pathology Lab with plot maintenance and sample collection.

Conflicts of Interest: The authors declare no conflict of interest.

\section{Appendix A}

Table A1. Variance components (standard deviations) for Site-Year and Block terms (random intercepts) and residuals, showing the relative variance accounted within each term.

\begin{tabular}{llll}
\hline & Gall Weight & Shoot Weight & Shoot Height \\
\hline Site-Year & $<0.0001$ & 201.2408 & 6.1035 \\
Block & $<0.0001$ & 131.4553 & 2.5843 \\
Residual & 1.1263 & 284.3762 & 4.8779 \\
\hline & Index of Disease Rating & Yield & Spore Density \\
\hline Site-Year & 0.4544 & 268.1289 & 0.3719 \\
Block & 0.0001 & 121.6343 & 0.4428 \\
Residual & 1.2064 & 391.4471 & 1.5088 \\
\hline
\end{tabular}

Table A2. Average total weed count per $\mathrm{m}^{2}$ and proportion of clubroot-susceptible weeds per $\mathrm{m}^{2}$ ( \pm standard deviation) at two field sites in Edmonton, Alberta, 2019, treated with hydrated lime for clubroot management.

\begin{tabular}{|c|c|c|c|c|c|c|}
\hline \multicolumn{3}{|c|}{ Treatment } & \multicolumn{2}{|c|}{ Average Total Weeds per $\mathrm{m}^{2}$} & \multicolumn{2}{|c|}{$\begin{array}{c}\text { Proportion of Susceptible } \\
\text { Weeds }(\%) \text { per } \mathrm{m}^{2}\end{array}$} \\
\hline Genetics $^{a}$ & Lime $^{b}$ & Weeds $^{c}$ & Site 2 & Site 3 & Site 2 & Site 3 \\
\hline Resistant & Lime & No Weeds & $0 \pm 0$ & $0 \pm 0$ & $0 \pm 0$ & $0 \pm 0$ \\
\hline Resistant & Lime & Weeds & $90.0 \pm 35.3$ & $93.0 \pm 21.1$ & $29.4 \pm 19.8$ & $49.7 \pm 27.3$ \\
\hline Resistant & No Lime & No Weeds & $0 \pm 0$ & $0 \pm 0$ & $0 \pm 0$ & $0 \pm 0$ \\
\hline Resistant & No Lime & Weeds & $111 \pm 14.4$ & $145 \pm 13.5$ & $36.4 \pm 7.5$ & $46.5 \pm 11.0$ \\
\hline
\end{tabular}


Table A2. Cont.

\begin{tabular}{|c|c|c|c|c|c|c|}
\hline \multicolumn{3}{|c|}{ Treatment } & \multicolumn{2}{|c|}{ Average Total Weeds per $\mathrm{m}^{2}$} & \multicolumn{2}{|c|}{$\begin{array}{l}\text { Proportion of Susceptible } \\
\text { Weeds (\%) per } \mathrm{m}^{2}\end{array}$} \\
\hline Genetics $^{a}$ & Lime $^{b}$ & Weeds $^{c}$ & Site 2 & Site 3 & Site 2 & Site 3 \\
\hline Susceptible & Lime & No Weeds & $0 \pm 0$ & $0 \pm 0$ & $0 \pm 0$ & $0 \pm 0$ \\
\hline Susceptible & Lime & Weeds & $95.5 \pm 36.7$ & $119 \pm 24.8$ & $20.5 \pm 8.2$ & $33.8 \pm 13.5$ \\
\hline Susceptible & No Lime & No Weeds & $0 \pm 0$ & $0 \pm 0$ & $0 \pm 0$ & $0 \pm 0$ \\
\hline Susceptible & No Lime & Weeds & $113 \pm 27.8$ & $109 \pm 16.6$ & $29.4 \pm 15.9$ & $46.7 \pm 6.2$ \\
\hline
\end{tabular}

a 'Genetics' refers to the canola cultivar grown (clubroot-susceptible '45H31' or clubroot-resistant '45CM39')

b 'Lime' refers to either the application of hydrated lime (Lime) or no application (No Lime). ${ }^{c}$ 'Weeds' refers to either the management (No Weeds) or non-management (Weeds) of weeds.

\section{References}

1. Dixon, G.R. The occurrence and economic impact of Plasmodiophora brassicae and clubroot disease. J. Plant Growth Regul. 2009, 28, 194-202. [CrossRef]

2. Dixon, G.R. The biology of Plasmodiophora brassicae Wor.-A review of recent advances. In IV International Symposium on Brassicas and XIV Crucifer Genetics Workshop; Lim, Y.P., Ed.; ISHS: Daejeon, Korea, 2006; Volume 1, pp. 271-282.

3. Howard, R.J.; Strelkov, S.E.; Harding, M.W. Clubroot of cruciferous crops-New perspectives on an old disease. Can. J. Plant Pathol. 2010, 32, 43-57. [CrossRef]

4. Creelman, D.W. Summary of the prevalence of plant diseases in Canada in 1965. A compilation. Can. Plant Dis. Surv. 1967, 47, 31-71.

5. Morasse, P.I.; Lafond, J. Attention à la hernie des cruifères dans le canola. Gd. Cult. 1997, 7, $22-23$.

6. Tewari, J.P.; Strelkov, S.E.; Orchard, D.; Hartman, M.; Lange, R.M.; Turkington, T.K. Identification of clubroot ofcrucifers on canola (Brassica napus) in Alberta. Can. J. Plant Pathol. 2005, 27, 143-144. [CrossRef]

7. Cao, T.; Manolii, V.P.; Strelkov, S.E.; Hwang, S.F.; Howard, R.J. Virulence and spread of Plasmodiophora brassicae [clubroot] in Alberta, Canada. Can. J. Plant Pathol. 2009, 31, 321-329. [CrossRef]

8. Strelkov, S.E.; Hwang, S.F. Clubroot in the Canadian canola crop: 10 years into the outbreak. Can. J. Plant Pathol. 2014, 36, 27-36. [CrossRef]

9. Froese, R.D.; Derksen, H.; Guo, X.; McLaren, D.L. Monitoring and occurrence of clubroot in Manitoba in 2018. The Canadian Phytopathological Society Canadian Plant Disease Survey: Disease Highlights. Can. J. Plant Pathol. 2019, 41, 179.

10. Ziesman, B.; Avila, R.; Ursu, K.; Kwasnicki, J.; Roszell, L.; Baraniecki, C.; Johnson, B.; Fennig, C.; Makohoniuk, K.; Junek, C.; et al. 2018 Clubroot survey and known occurrence of clubroot in Saskatchewan. The Canadian Phytopathological Society Canadian Plant Disease Survey: Disease Highlights. Can. J. Plant Pathol. 2019, 41, 159-161.

11. Pageau, D.; Lajeunesse, J.; Lafond, J. Impact of clubroot [Plasmodiophora brassicae] on the yield and quality of canola. Can. J. Plant Pathol. 2006, 28, 137-143. [CrossRef]

12. Strelkov, S.E.; Manolii, V.P.; Cao, T.; Xue, S.; Hwang, S.F. Pathotype classification of Plasmodiophora brassicae and its occurrence in Brassica napus in Alberta, Canada. J. Phytopathol. 2007, 155, 706-712. [CrossRef]

13. The Economic Impact of Canola on the Canadian Economy by LMC International. Available online: https://www.canolacouncil. org/download/215/pages/5255/1mc_canola_10-year_impact_study_-_canada_final_dec_2016 (accessed on 5 September 2019).

14. Rahman, H.; Peng, G.; Yu, F.; Falk, K.C.; Kulkarni, M.; Selvaraj, G. Genetics and breeding for clubroot resistance in Canadian spring canola (Brassica napus L.). Can. J. Plant Pathol. 2014, 36, 122-134. [CrossRef]

15. Hwang, S.-F.; Strelkov, S.E.; Feng, J.; Gossen, B.D.; Howard, R.J. Plasmodiophora brassicae: A review of an emerging pathogen of the Canadian canola (Brassica napus) crop. Mol. Plant Pathol. 2012, 13, 105-113. [CrossRef] [PubMed]

16. Strelkov, S.E.; Hwang, S.-F.; Manolii, V.P.; Cao, T.; Feindel, D. Emergence of new virulence phenotypes of Plasmodiophora brassicae on canola (Brassica napus) in Alberta, Canada. Eur. J. Plant Pathol. 2016, 145, 517-529. [CrossRef]

17. Strelkov, S.E.; Hwang, S.-F.; Manolii, V.P.; Cao, T.; Fredua-Agyeman, R.; Harding, M.W.; Peng, G.; Gossen, B.D.; Mcdonald, M.R.; Feindel, D. Virulence and pathotype classification of Plasmodiophora brassicae populations collected from clubroot resistant canola (Brassica napus) in Canada. Can. J. Plant Pathol. 2018, 40, 284-298. [CrossRef]

18. Hollman, K.B.; Hwang, S.-F.; Manolii, V.P.; Strelkov, S.E. Pathotypes of Plasmodiophora brassicae collected from clubroot resistant canola (Brassica napus L.) cultivars in western Canada in 2017-2018. Can. J. Plant Pathol. 2021, 43, 622-630. [CrossRef]

19. Fox, N.M.; Hwang, S.-F.; Manolii, V.P.; Turnbull, G.; Strelkov, S.E. Evaluation of Lime Products for Clubroot (Plasmodiophora brassicae) Management in Canola (Brassica napus) Cropping Systems. Can. J. Plant Pathol. 2021, 44, 21-38. [CrossRef]

20. Karling, J.S. The Plasmodiophorales, 1st ed.; John, S. Karling: New York, NY, USA, 1942; pp. 110-114.

21. Zamani-Noor, N.; Rodemann, B. Reducing the build-up of Plasmodiophora brassicae inoculum by early management of oilseed rape volunteers. Plant Pathol. 2018, 67, 426-432. [CrossRef]

22. Alberta Agriculture, Food and Rural Development, Agri-Facts Liming. Available online: https://open.alberta.ca/dataset/8a143 d84-86a5-45b0-a432-d35f269de006/resource/d75bfaef-e123-4bfe-bea4-500e1e70e46e/download/1996-534-1.pdf (accessed on 1 December 2020). 
23. Penney, D. Crop Response to Liming Acid Soils of Alberta and Northeastern British Columbia. Master's Thesis, University of Alberta, Edmonton, AB, Canada, 1973.

24. Kuginuki, Y.; Hiroaki, Y.; Hirai, M. Variation in virulence of Plasmodiophora brassicae in Japan tested with clubroot-resistant cultivars of Chinese cabbage (Brassica rapa L. ssp. pekinensis). Eur. J. Plant Pathol. 1999, 105, 327-332. [CrossRef]

25. Horiuchi, S.; Hori, M. A simple greenhouse technique for obtaining high levels of clubroot incidence. Bull. Chugoku Natl. Agric. Exp. Stn. Ser. E 1980, 17, 33-55.

26. Strelkov, S.E.; Tewari, J.P.; Smith-Degenhardt, E. Characterization of Plasmodiophora brassicae populations from Alberta, Canada. Can. J. Plant Pathol. 2006, 28, 467-474. [CrossRef]

27. Cao, T.; Tewari, J.; Strelkov, S.E. Molecular detection of Plasmodiophora brassicae, causal agent of clubroot of crucifers, in plant and soil. Plant Dis. 2007, 91, 80-87. [CrossRef] [PubMed]

28. Rennie, D.C.; Manolii, V.P.; Cao, T.; Hwang, S.F.; Howard, R.J.; Strelkov, S.E. Direct evidence of surface infestation of seeds and tubers by Plasmodiophora brassicae and quantification of spore loads. Plant Pathol. 2011, 60, 811-819. [CrossRef]

29. R Core Team. R: A Language and Environment for Statistical Computing; R Foundation for Statistical Computing: Vienna, Austria, 2021; Available online: https:/ / www.R-project.org/.

30. Pinheiro, J.; Bates, D.; DebRoy, S.; Sarkar, D. R Core Team. Linear and Nonlinear Mixed Effects Models. R Package Version 3.1-153. 2021. Available online: https:/ /CRAN.R-project.org/package=nlme/.

31. Russell, V. Lenth. Emmeans: Estimated Marginal Means, aka Least-Squares Means. R Package Version 1.7.2. 2022. Available online: https: / CRAN.R-project.org/package=emmeans.

32. Hothorn, T.; Bretz, F.; Westfall, P. Simultaneous Inference in General Parametric Models. Biom. J. 2008, 50, 346-363. [CrossRef] [PubMed]

33. Wickham, H. ggplot2: Elegant Graphics for Data Analysis; Springer: New York, NY, USA, 2016.

34. Lüdecke, D. ggeffects: Tidy Data Frames of Marginal Effects from Regression Models. J. Open Source Softw. 2018, 3, 772. [CrossRef]

35. Kassambara, A. ggpubr: 'ggplot2' Based Publication Ready Plots. R Package Version 0.4.0. 2020. Available online: https: / /CRAN.R-project.org / package=ggpubr.

36. Hwang, S.-F.; Ahmed, H.U.; Strelkov, S.E.; Gossen, B.D.; Turnbull, G.D.; Peng, G.; Howard, R.J. Seedling age and inoculum density affect clubroot severity and seed yield in canola. Can. J. Plant Sci. 2011, 91, 183-190. [CrossRef]

37. Peng, G.; Lahlali, R.; Hwang, S.-F.; Pageau, D.; Hynes, R.K.; McDonald, M.-R.; Gossen, B.D.; Strelkov, S.E. Special Issue: Crop rotation, cultivar resistance, and fungicides/biofungicides for managing clubroot (Plasmodiophora brassicae) on canola. Can. J. Plant Pathol. 2014, 36, 99-112. [CrossRef]

38. Xue, S.; Cao, T.; Howard, R.J.; Hwang, S.-F.; Strelkov, S.E. Isolation and variation in virulence of single-spore isolates of Plasmodiophora brassicae from Canada. Plant Dis. 2008, 92, 456-462. [CrossRef]

39. Strelkov, S.E.; Manolii, V.P.; Harding, M.W.; Daniels, G.C.; Nuffer, P.; Aigu, Y.; Hwang, S.-F. The Occurrence and spread of clubroot on canola in Alberta in 2019. Can. J. Plant Pathol. 2020, 42, 117-120.

40. Fredua-Agyeman, R.; Hwang, S.F.; Strelkov, S.E.; Zhou, Q.; Feindel, D. Potential loss of clubroot resistance genes from donor parent Brassica rapa subsp. rapifera (ECD 04) during doubled haploid production. Plant Pathol. 2018, 67, 892-901. [CrossRef]

41. Canola Council of Canada. Clubroot. Available online: https://www.canolacouncil.org/canola-encyclopedia/diseases/clubroot/ (accessed on 10 December 2020).

42. Hwang, S.-F.; Strelkov, S.E.; Ahmed, H.U.; Manolii, V.P.; Zhou, Q.; Fu, H.; Turnbull, G.; Freuda-Agyeman, R.; Feindel, D. Virulence and inoculum density-dependent interactions between clubroot resistant canola (Brassica napus) and Plasmodiophora brassicae. Plant Pathol. 2017, 66, 1318-1328. [CrossRef]

43. Ernst, T.W.; Kher, S.; Stanton, D.; Rennie, D.C.; Hwang, S.-F.; Strelkov, S.E. Plasmodiophora brassicae resting spore dynamics in clubroot resistant canola (Brassica napus) cropping systems. Plant Pathol. 2019, 68, 399-408. [CrossRef]

44. Tremblay, N.; Bélec, C.; Coulombe, J.; Godin, C. Evaluation of calcium cyanamide and liming for control of clubroot disease in cauliflower. Crop Prot. 2005, 24, 798-803. [CrossRef]

45. Binkley, D.; Vitousek, P. Soil Nutrient Availability. In Plant Physiological Ecology; Springer: Dordrecht, The Netherlands, 1991; pp. 75-96.

46. Cornell University, Agronomy Fact Sheet \#5: Soil pH for Field Crops. Available online: http://nmsp.cals.cornell.edu/guidelines/ factsheets.html (accessed on 11 October 2020).

47. Oerke, E.C. Crop Losses to Pests. J. Agric. Sci. 2006, 144, 31-43. [CrossRef]

48. Niwa, R.; Nomura, Y.; Osaki, M.; Ezawa, T. Suppression of clubroot disease under neutral pH caused by inhibition of spore germination of Plasmodiophora brassicae in the rhizosphere. Plant Pathol. 2008, 57, 445-452. [CrossRef]

49. Donald, C.; Porter, I. Integrated control of clubroot. J. Plant Growth Regul. 2009, 28, 289. [CrossRef]

50. Dixon, G.R. Clubroot (Plasmodiophora brassicae Woronin)—An agricultural and biological challenge worldwide. Can. J. Plant Pathol. 2014, 36, 5-18. [CrossRef]

51. Hwang, S.-F.; Howard, R.J.; Strelkov, S.E.; Gossen, B.D.; Peng, G. Management of clubroot (Plasmodiophora brassicae) on canola (Brassica napus) in western Canada. Can. J. Plant Pathol. 2014, 36, 49-65. [CrossRef] 